\title{
Water purification and antibacterial efficacy of Moringa oleifera Lam
}

\author{
Ashenafi Delelegn, Samuel Sahile and Azamal Husen * ${ }^{*}$
}

\begin{abstract}
Background: Plants are rich in secondary metabolites and are being used for the treatment of various ailments in the indigenous system of medicine. Many developing countries are facing illnesses, and deaths among children are caused by germs, which get into the mouth via water and food. In addition, it has been estimated that up to $80 \%$ of all disease and sickness in the world is caused by inadequate sanitation, polluted water or unavailability of water. Thus, this study investigates the water purifying property of Moringa oleifera seed powder and determines the role of seed extracts against a few bacterial growths.
\end{abstract}

Methods: Water samples were obtained randomly during January and February, 2015, from the Angereb and Shinta rivers, Gondar, Ethiopia. Both sites of water samples were subjected for purification studies and treated with dried seed powder. Treated water samples were subjected to bacteriological analysis using most probable number technique.

Results: Addition of aluminum sulfate as a coagulant lowered the water $\mathrm{pH}$ from 7.2 to 3.66 , while the seed extract water $\mathrm{pH}$ remained the same. Treatment of $0.016 \mathrm{~g} / \mathrm{L}$ of M. oleifera decreased water turbidity from 208.3 nephelometric turbidity units (NTU) to 33.66 NTU (83.84\%) and from 129 NTU to 16.8 NTU (86.98\%) for the Shinta and Angereb river water samples, respectively. The highest microbial load reduction was found with the Angereb (97.17\%) and Shinta (97.50\%) rivers. The acetone extracts showed maximum antibacterial activity with $19.00 \mathrm{~mm}$ against Salmonella typhii (clinical isolate), while Shigella dysenteriae (clinical isolate) was the least sensitive with $7.66 \mathrm{~mm}$ on the aqueous extract. The most frequent MIC value was $6.25 \mathrm{mg} / \mathrm{mL}$ followed by $12.5 \mathrm{mg} / \mathrm{mL}$. The acetone extract is the most potent in inhibiting and killing the test organisms at a very low concentration for Shigella typhii.

Conclusion: Taken together, the seed powder exhibits a remarkable reduction in turbidity and coliform count which makes the seed powder a good source for water purification. The acetone extract of seed had a strong antibacterial activity. It reveals that the seed powder and its extract can control and reduce waterborne bacterial diseases. This investigation facilitates benefits to those who cannot afford and or have access to clean drinking water in Ethiopia and elsewhere.

Keywords: Moringa, Seed, Water, Microbes, MIC, MBC

\section{Background}

Ethiopia is a tropical country which is endowed with rich plant biodiversity, and there are many plant species found in this country for medicinal purposes, and it is often reported and explored [1]. Many local healers in developing countries still depend on traditional medicines for

${ }^{*}$ Correspondence: adroot92@yahoo.co.in

Department of Biology, College of Natural and Computational Science, University of Gondar, P.O. Box 196, Gondar, Ethiopia their primary healthcare. Therefore, such plants should be investigated to understand their properties, safety and efficiency for various types of exploitation. Different plant parts are rich in a wide variety of secondary metabolites such as tannins, terpenoids, alkaloids, flavonoids, glycosides, which have been found to have antimicrobial properties [2-4]. In recent days, these plant metabolites are also used in the fabrication of metal and metal oxide nanoparticles, which have shown effective antimicrobial properties [5-10]. Moringa oleifera Lam. belongs to 
the family Moringaceae and is a valuable plant, found in many countries of the tropics and subtropics. Its leaves, fruit, flowers and immature pods are used as a highly nutritive vegetable in many countries, particularly in India, Pakistan, Philippines, Hawaii and many parts of Africa [3]. Seed extract is observed to have a protective effect by decreasing liver lipid peroxides and is antihypertensive [11-13]. M. oleifera roots, leaves, seed, fruit, flowers, bark and immature pods are used as cardiac and circulatory stimulants, contain antipyretic, antiepileptic, antitumor, antiinflammatory, antiulcer, diuretic, antihypertensive, cholesterol lowering, antispasmodic, antidiabetic, hepatoprotective, antioxidant, antibacterial and antifungal activities, and are being used for the treatment of various ailments in the indigenous system of medicine [3].

Water is used for several purposes by humans, but the level of purity of the water being consumed is very crucial since it has a direct effect on health. More than half of all illnesses and deaths among children are caused by germs, which get into the mouth via water and food. The World Health Organization has estimated that up to $80 \%$ of all disease and sickness in the world is caused by inadequate sanitation, polluted water or unavailability of water [13]. Every day 2 million tonnes of sewage, industrial and agricultural waste is discharged into the world's water [14], the equivalent of the weight of the entire human population of 6.8 billion people. According to UN estimates, the amount of wastewater produced annually is about $1500 \mathrm{~km}^{3}$, six times more than that exists in all the rivers of the world [14].

Lake Tana occupies a wide depression in the Ethiopian plateau and is the largest lake in the country. The lake is the source of the Blue Nile river with a total surface area of $3600 \mathrm{~km}^{2}$, a volume of $28 \mathrm{~km}^{3}$ and an average elevation of $1911 \mathrm{~m}$ above the sea level. More than 40 small and big rivers are reported to feed Lake Tana. It is located at a latitude of $12\left(12^{\circ} 0^{\prime} 0 \mathrm{~N}\right)$ and a longitude of $37.33\left(37^{\circ} 19^{\prime} 60 \mathrm{E}\right)$. It was formed by a volcanic blockage that reversed the previously north-flowing Blue Nile river and created one of Africa's greatest waterfalls. The majority of people living around Lake Tana and its rivers are still utilizing water for drinking and other routine activities without any purification. It has been found that the dry seeds of $M$. oleifera are used in place of aluminum sulfate by rural women to treat highly turbid Nile water. It has also been reported that when the crushed seeds are added to raw water, the proteins produce positive charges acting like magnets and attracting the predominantly negatively charged particles (such as clay, silt, bacteria and other toxic particles in water) [15]. Crushed seeds are also capable of attracting and sticking fast to bacteria and viruses that are found in contaminated and turbid water
[16]. A comparative study has also been carried out with harvesting surface rainwater and its purification by using seed extracts and aluminum sulfate [17]. Seeds have also shown antimicrobial activity $[18,19]$. Most of the workers have reported the use of leaf and or bark extracts elsewhere, while the scientific and effective use of $M$. oleifera dried seed powder for water purification and antibacterial efficacy under Gondar, Ethiopia agro-climatic zone is not reported so far. Therefore, the present study was designed. In this study, the water purifying property of the seed powder specifically for the Angereb and Shinta rivers and the role of seed extracts against bacterial growth namely Escherichia coli (ATCC2592), E. coli (clinical isolate), Salmonella typhii (clinical isolate) and Shigella dysenteriae (clinical isolate) were examined.

\section{Methods}

Study area

Gondar is bounded by $12035^{\prime} 07^{\prime \prime}$ North latitude and $37026^{\prime} 08^{\prime \prime}$ East longitude, and it has a narrow range of altitude, i.e., $2000-2200 \mathrm{~m}$ above the sea level, which is north of Lake Tana and southwest of the Simien Mountains. The Angereb river is a river of Ethiopia and eastern Sudan and one of the sources of the Nile river found in Gondar town. It flows west to join the Atbarah river [20]. The other river flowing in Gondar is the Shinta. The Shinta contributes to the Angereb river which is a part of the tributaries of Lake Tana. The Shinta river drains from north to south, and it serves as natural sewerage lines for domestic and industrial wastes [21]. All samples were labeled and transported to the Tewodros campus Microbiology Laboratory, Department of Biology, University of Gondar, Gondar, Ethiopia, and stored at $4{ }^{\circ} \mathrm{C}$ for further studies.

\section{Plant material collection, identification and treatments}

Seeds of Moringa oleifera used in this study were obtained from the Agricultural and Forestry office, Adirkay, Gondar. Adirkay district has a latitude and longitude of $13^{\circ} 29^{\prime} 50^{\circ} 60^{\prime} \mathrm{N} 38^{\circ} 03^{\prime} 25.96^{\circ} \mathrm{E}$ with an elevation of $2025 \mathrm{~m}$ above the sea level. The area is predominately rural and most residents live in villages as agriculturists. The experiment was carried out during October 2014 to May 2015 in the Microbiology Laboratory, Department of Biology, University of Gondar, Ethiopia. The treatments given were the varying concentrations of powder produced from $M$. oleifera seeds and the positive and negative control (aluminum sulfate and no seed powder, respectively) for water purification. Further, the varying concentration of extracts with different solvents was produced from $M$. oleifera seeds and the positive control (ciprofloxacin) was used for antibacterial test. 


\section{Extraction of Moringa seed powder and antimicrobial test organisms}

Mature seeds of $M$. oleifera were chosen from dry cracked fruits. The plucked fruits were cracked to obtain the seeds which were air-dried for 2 days. The shells surrounding the seed kernels were removed using a knife, and the kernels were powdered using a laboratory mortar and pestle and sieved using a sieve with a pore size of $2.5 \mathrm{~mm}^{2}$ to obtain a fine powder. The powder was stored in a sterile bottle at room temperature in a dark place. The powdered sample was successively extracted with methanol, acetone and aqueous in increasing polarity. In this procedure, $50 \mathrm{~g}$ of $M$. oleifera powdered seeds was soaked in $250 \mathrm{~mL}$ of each of the solvents which were acetone, methanol and aqueous and in all cases equal volumes of solvents were used. They were left shaking on a horizontal shaker for 3 days. Then, the extracts were filtered separately through Whatman no.1 filter paper. The filtrates were then centrifuged at $5000 \mathrm{rpm}$ for $15 \mathrm{~min}$. The supernatant of each extract was evaporated by using Rota vapor (Laborator 4000-efficient, Heidolph, Germany). The crude extracts were stored at $4{ }^{\circ} \mathrm{C}$. The yields of acetone, methanol and water extracts weighed 16, 15 and 13\%, respectively. Each test was replicated three times [22]. The antibacterial properties of the crude extracts were tested against the test organisms. Pure cultures of Escherichia coli (ATCC 2592) were taken from the microbiology laboratory, Department of Biology, while E. coli (clinical isolate), Salmonella typhii (clinical isolate) and Shigella dysenteriae (clinical isolate) were obtained from the Gondar College of Medical Science, University of Gondar, Ethiopia. Organisms were chosen based on reports of their human and livestock pathogenicity in water.

\section{Sample preparation and laboratory analyses}

Forty liters of raw water samples were fetched from the Shinta and Angereb rivers. Thereafter, dispensed into six beakers containing $500 \mathrm{~mL}$ each for $M$. oleifera and aluminum sulfate. Five different concentrations of the stock solution for the loading dose were prepared by weighing 2.0, 4.0, 6.0, 8.0 and $10.0 \mathrm{~g}$ of $M$. oleifera seed powder and aluminum sulfate each separately into a beaker containing $500 \mathrm{ml}$ of distilled water. The mixtures in the beakers were stirred using a glass rod to obtain a clear solution. A $500 \mathrm{ml}$ of distilled water with no M. oleifera seed powder extract was kept as negative control [23]. Two $\mathrm{ml}$ of the various concentrations including the control of all the loading dosages prepared was measured into a beaker containing $500 \mathrm{ml}$ of the sample river water. The solutions were mixed rapidly for $2 \mathrm{~min}$, followed by 10 min of gentle mixing using a sterile glass rod to aid in coagulant formation. The suspensions were left to stand without disturbance for $1 \mathrm{~h}$. This is the method adopted since there is no standard method for conducting the jar test [24]. The supernatants formed were recovered and subjected to total coliforms count, $\mathrm{pH}$ and turbidity measurements.

\section{Total coliform using most probable number (MPN) test}

In determining the MPN of coliforms that were present in each of the treated water samples, the multiple tube fermentation method was adopted. Lauryl tryptose broth (LTB) tubes were used for the bacteria growth. Two types of the LTB tubes were prepared. These were the singlestrength lauryl tryptose broth (SSLTB) and the doublestrength lauryl tryptose broth (DSLTB). In the single strength, $6.5 \mathrm{~g}$ of the LTB powder was weighed and dissolved in $500 \mathrm{ml}$ of distilled water. The double strength was prepared using exactly twice the weights of the reagents used and stirred gently for $10 \mathrm{~min}$ as it was done in the single-strength LTB preparation [25]. An estimate of the number of the coliforms (most probable number) was done in the presumptive test. In this procedure, 15 test tubes with $15 \mathrm{ml}$ of lauryl tryptose broth were inoculated with $10 \mathrm{~mL}$ of treated water samples and the control at different intervals. Five tubes received $10 \mathrm{ml}$ of water, the LTB used was double strength for this case, other five tubes received $1 \mathrm{ml}$ of water, and the last five tubes received $0.1 \mathrm{ml}$ of water. Here, the last 10 tubes contained single-strength LTB. The test tubes were then incubated for $24-48 \mathrm{~h}$ at $37{ }^{\circ} \mathrm{C}$. For confirmatory test, from each positive presumptive test tube three loopful of samples were transferred to test tubes containing brilliant green lactose bile broth (BGLB), further incubated at $37{ }^{\circ} \mathrm{C}$ for $24 \mathrm{~h}$ and inspected for the presence of gas. The number of tubes showing gas production was counted, and the figure was compared to a table developed by the American Public Health Association [26]. The number was the MPN of coliform per $100 \mathrm{ml}$ of the water sample [27].

\section{Turbidity and $\mathrm{pH}$ measurement}

Turbidity was determined by the nephelometric method using turbidimeter on water samples on the jar tests. The turbidity level of the water samples was measured before and after treatment of the sample with different doses of $M$. oleifera seed powder and aluminum sulfate using turbidity meter. A test tube was filled with the sample to the $10 \mathrm{ml}$ mark, and turbidity meter reading was taken against the blank tube. The result was read directly from the turbidity meter display and reported as nephelometric turbidity units (NTU) [28]. A buffer solution calibrated $\mathrm{pH}$ meter was used to measure the hydrogen ion concentration of the water before and after treatment with Moringa seed powder and aluminum sulfate. Accordingly, the result was read from the display [29]. In 
addition, McFarland standard was comparable to a bacterial suspension of $1.5 \times 10^{8} \mathrm{cell} / \mathrm{mL}$ [30].

\section{Antimicrobial tests using different methods}

The isolates were preserved on nutrient agar plate and incubated at $37{ }^{\circ} \mathrm{C}$ for $24 \mathrm{~h}$ according to the manufacturer's specification. The isolates were preserved on agar slant and stored at $4{ }^{\circ} \mathrm{C}$ until further use. A loopful of the test organisms was inoculated into sterile normal saline. The bacterial suspension was compared to the 0.5 McFarland standards [31]. The antibacterial assay was performed by agar well diffusion technique, and MIC and MBC were determined.

\section{Agar well diffusion}

Bacterial broth culture was prepared to a density of $10^{8}$ cells $\mathrm{mL}^{-1}$ of $0.5 \mathrm{McF}$ arland standards. The aliquot was spread evenly onto Mueller-Hinton agar using a sterilized cotton swab. Then, the plated medium was allowed to dry at room temperature for $30 \mathrm{~min}$ [32]. On each plate, equidistant wells were prepared with a 6-mmdiameter sterilized, cork borer, which were $2 \mathrm{~mm}$ from the edge of the plate. Fifty microliters of each extract $(50 \mathrm{mg} / \mathrm{mL})$ was aseptically introduced into a respective agar well. Ciprofloxacin $(25 \mu \mathrm{g} / \mathrm{mL})$ was used as standard (positive) control and sample free solutions as blank control. This was followed by allowing the agar plate on the bench for $40 \mathrm{~min}$ pre-diffusion followed by incubation at $37^{\circ} \mathrm{C}$ for $24-48 \mathrm{~h}$. The formation of clear inhibition zone of $\geq 7 \mathrm{~mm}$ diameters around the wells was regarded as significant susceptibility of the organisms to the extract [33]. The experiment was performed in triplicates.

Determination of minimum inhibitory concentration (MIC) The MIC was determined for extracts that showed $\geq 7 \mathrm{~mm}$ diameter growth inhibition zone. The test was performed using agar dilution method. In this technique, a serial of twofold dilution of the extract was prepared in Mueller-Hinton agar. The bacterial inoculum which was standardized according to the McFarland standard was inoculated on the surface of the agar. The extract solution $(50 \mathrm{mg} / \mathrm{mL})$ was serially diluted as $1: 2,1: 4$ and 1:8 to bring $25,12.5$ and $6.25 \mathrm{mg} / \mathrm{mL}$ concentrations, respectively [22]. The extracts were then aseptically introduced as described above. The inhibition of growth was assessed after $24 \mathrm{~h}$ incubation at $37^{\circ} \mathrm{C}$, and the minimum concentration that inhibited growth was considered as MIC value of the extract.

\section{Determination of the minimum bactericidal concentration (MBC)}

The MBC of the plant extracts was determined by the modified method of Spencer and Spencer [34]. The plates that showed no growth after incubation of the batch of agar plates on MIC were sub-cultured on Mueller-Hinton agar plates and incubated at $37^{\circ} \mathrm{C}$ for $24 \mathrm{~h}$. The highest dilution (least concentration) that yielded no single bacterial colony and showed no visible growth after incubation was taken as the MBC.

\section{Statistical analysis}

Data were analyzed using SPSS (version 16) statistical software. Mean coliform and turbidity reduction were calculated. One-way ANOVA was used to test existence of statistically significant difference between mean zones of inhibition. A significance level of $p$ value less than 0.05 was used.

\section{Results}

\section{Water purification}

The raw water turbidity of the Angereb and Shinta rivers was found to be 129 NTU and 208.30 NTU, respectively. Results have shown that the lowest concentration of aluminum sulfate exhibited maximum turbidity reduction. Aluminum sulfate at $0.016 \mathrm{~g} / \mathrm{L}$ reduced turbidity from 129 NTU to 2.1 NTU (98.37\%) for the Angereb, while the same concentration was found to be $208.30 \mathrm{NTU}$ to 1.86 NTU (99.11\%) for the Shinta water sample, after an hour of settling time. Further, $M$. oleifera seed powder at $0.016 \mathrm{~g} / \mathrm{L}$ reduced turbidity from $129.00 \mathrm{NTU}$ to 16.8 NTU (86.98\%) for the Angereb and from 208.3 NTU to $33.66 \mathrm{NTU}$ (83.84\%) for the Shinta river water. However, higher concentrations of $M$. oleifera seed powder have shown increased water turbidity. This trend was observed in both river water samples (Table 1, Fig. 1a, b). Further, $\mathrm{pH}$ of raw water samples was obtained to be 6.7 for Angereb and 7.2 for Shinta river before treatment. Significant reduction in $\mathrm{pH}$ was observed at $0.064 \mathrm{~g} / \mathrm{L}$ of aluminum sulfate which was to $3.76(43.88 \%)$ and 3.66 (49.17\%) for the Angereb and Shinta river water samples, respectively. Unlike aluminum sulfate, there was no significant effect on $\mathrm{pH}$ of both water samples observed after treatment with different concentrations of $M$. oleifera, except a slight reduction from 6.7 to 6.43 (4.03\%) for the Angereb at a concentration of $0.016 \mathrm{~g} / \mathrm{L}$ and a reduction of $\mathrm{pH}$ from 7.2 to 6.9 (4.17\%) for Shinta river water samples observed at a concentration of $0.032 \mathrm{~g} / \mathrm{L}$ (Table 1).

The result of coliform count expressed as the most probable number (MPN) of both raw and treated water samples is given in Table 2 . For both treated and untreated water samples, the coliform counts exhibit significant variation for the Angereb and Shinta river waters. There was a significant reduction of coliform counts in the treated water samples. The MPN tests were carried out using $M$. oleifera seed powder, and it 
Table 1 Turbidity and pH of two water samples (Angereb and Shinta rivers) treated with Moringa oleifera and aluminum sulfate after $1 \mathrm{~h}$ settling time

\begin{tabular}{|c|c|c|c|c|c|c|}
\hline \multirow[t]{2}{*}{ Treatments } & \multirow[t]{2}{*}{ Water source } & \multirow[t]{2}{*}{ Treatment (g/L) } & \multicolumn{2}{|l|}{$\mathrm{pH}$} & \multicolumn{2}{|l|}{ Turbidity (NTU) } \\
\hline & & & Mean reduction $\pm S D$ & $\%$ reduction & $\begin{array}{l}\text { Mean reduction } \\
(\mathrm{NTU}) \pm S D\end{array}$ & $\%$ reduction \\
\hline \multirow[t]{12}{*}{ Moringa oleifera seed powder } & \multirow[t]{6}{*}{ Angereb } & Control & $6.70 \pm 0.00$ & 0 & $129.00 \pm 0.00$ & 0 \\
\hline & & 0.016 & $6.43 \pm 0.45$ & 4.03 & $16.80 \pm 0.10$ & 86.98 \\
\hline & & 0.032 & $6.60 \pm 0.43$ & 1.49 & $33.56 \pm 1.00$ & 73.98 \\
\hline & & 0.048 & $6.53 \pm 0.57$ & 2.54 & $31.33 \pm 0.47$ & 75.71 \\
\hline & & 0.064 & $6.70 \pm 0.00$ & 0 & $29.06 \pm 0.56$ & 77.47 \\
\hline & & 0.08 & $6.90 \pm 0.10$ & -2.99 & $34.66 \pm 2.38$ & 73.13 \\
\hline & \multirow[t]{6}{*}{ Shinta } & Control & $7.20 \pm 0.00$ & 0 & $208.30 \pm 0.00$ & 0 \\
\hline & & 0.016 & $7.30 \pm 0.10$ & 5 & $33.66 \pm 0.80$ & 83.84 \\
\hline & & 0.032 & $6.86 \pm 0.57$ & 4.72 & $43.20 \pm 1.24$ & 79.26 \\
\hline & & 0.048 & $7.03 \pm 0.15$ & 2.36 & $48.60 \pm 0.43$ & 76.67 \\
\hline & & 0.064 & $6.90 \pm 0.00$ & 4.17 & $44.80 \pm 0.88$ & 78.49 \\
\hline & & 0.08 & $7.23 \pm 0.15$ & -0.42 & $42.50 \pm 0.84$ & 79.60 \\
\hline \multirow[t]{12}{*}{ Aluminum sulfate } & \multirow[t]{6}{*}{ Angereb } & Control & $6.70 \pm 0.00$ & 0 & $129.00 \pm 0.00$ & 0 \\
\hline & & 0.016 & $4.40 \pm 0.20$ & 34.33 & $2.10 \pm 0.10$ & 98.37 \\
\hline & & 0.032 & $4.10 \pm 0.10$ & 38.81 & $2.50 \pm 0.10$ & 98.06 \\
\hline & & 0.048 & $4.00 \pm 0.20$ & 40.30 & $2.66 \pm 0.057$ & 97.94 \\
\hline & & 0.064 & $3.76 \pm 0.05$ & 43.88 & $3.60 \pm 0.00$ & 97.20 \\
\hline & & 0.08 & $3.93 \pm 0.05$ & 41.34 & $2.90 \pm 0.10$ & 97.75 \\
\hline & \multirow[t]{6}{*}{ Shinta } & Control & $7.20 \pm 0.00$ & 0 & $208.30 \pm 0.00$ & 0 \\
\hline & & 0.016 & $4.46 \pm 0.05$ & 38.06 & $1.86 \pm 0.057$ & 99.11 \\
\hline & & 0.032 & $4.83 \pm 0.05$ & 32.92 & $2.20 \pm 0.20$ & 98.94 \\
\hline & & 0.048 & $4.23 \pm 0.25$ & 41.25 & $2.36 \pm 0.05$ & 98.87 \\
\hline & & 0.064 & $3.66 \pm 0.15$ & 49.17 & $2.26 \pm 0.15$ & 98.92 \\
\hline & & 0.08 & $3.93 \pm 0.15$ & 45.42 & $2.86 \pm 0.57$ & 98.63 \\
\hline
\end{tabular}

was observed that both untreated water samples contained greater than 2400 coliforms $/ 100 \mathrm{~mL}$. For lowest concentration $0.016 \mathrm{mg} / \mathrm{L}$, the MPN was found to be 500 coliforms $/ 100 \mathrm{~mL}$ and 900 coliforms/100 mL for the Angereb and Shinta river waters, respectively. However, at the highest concentration $(0.08 \mathrm{mg} / \mathrm{L})$, the MPN was observed to be 70 coliforms $/ 100 \mathrm{ml}$ and 60 coliforms $/ 100 \mathrm{~mL}$ for the Angereb and Shinta river waters, respectively. Furthermore, the percent variation for both the water sources is presented in Table 2 .

\section{Antibacterial activity}

From the agar well diffusion result, it was found that $E$. coli (ATCC 2592) was significantly susceptible to all extracts $(p=0.008)$. However, the acetone extract had the maximum (13.33) antibacterial activity against $E$. coli (ATCC 2592), while the aqueous extract had the minimum (8.33) antibacterial activity against $E$. coli (ATCC 2592). The sensitivity of E. coli (ATCC 2592) to the methanol extracts (9.66) also significantly varied from the aqueous extract. E. coli (clinical isolate) response also significantly varied among the studied extracts $(p=0.04)$. The acetone extract had maximum (18.00) antibacterial activity against $E$. coli (clinical isolate) in comparison with the other extracts. E. coli (clinical isolate) showed moderate sensitivity (15.66) with the methanol extract, while the lowest (8.33) sensitivity was with the aqueous extract. Salmonella typhii (clinical isolate) was also significantly susceptible to all extracts $(p=0.026)$. Among the used $M$. oleifera seed extracts, the acetone has shown maximum (19.00) antibacterial activity against Salmonella typhii (clinical isolate) followed by methanol (15.33) and then the aqueous (7.66) extract. Further for Shigella dysenteriae (clinical isolate), the acetone extract has shown a maximum and significant variation in comparison with the other extracts. Therefore, the acetone has shown maximum (18.66) antibacterial activity against Salmonella typhii (clinical isolate) followed by the methanol (17.00) and then the aqueous (7.66) extract. However, in comparison with the used M. oleifera seed extracts, ciprofloxacin was considered as a standard drug and 


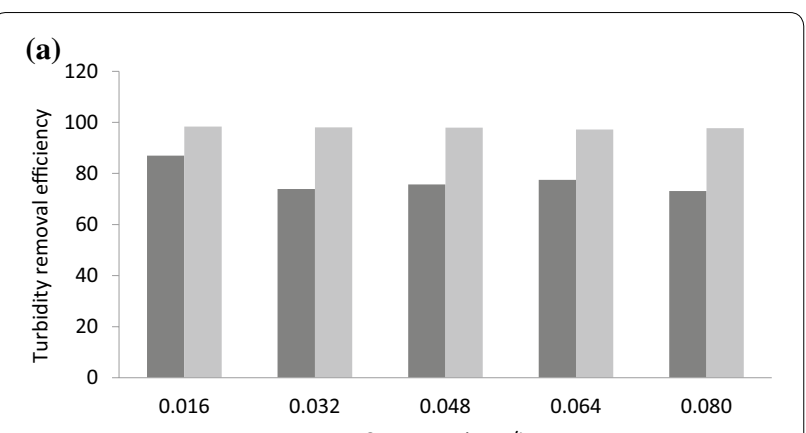

(b)

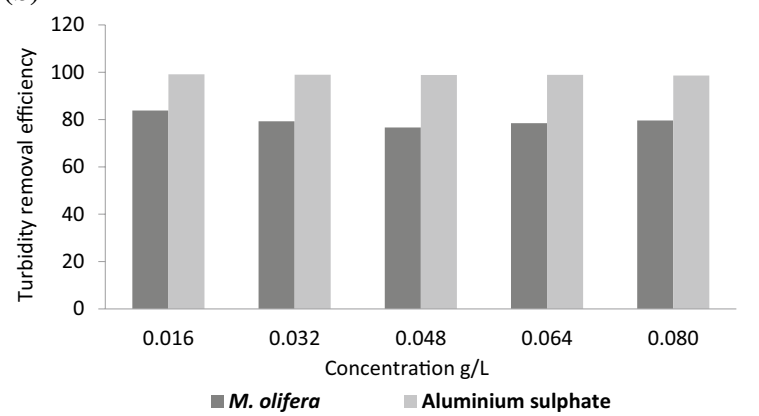

Fig. 1 Percent variation from the control, as observed for the turbidity reduction after treatment of $\mathbf{a}$ Angereb, $\mathbf{b}$ Shinta river water samples with various concentrations of Moringa oleifera and aluminum sulfate

was found to be the best by showing maximum activity against the all tested bacterial growth (Table 3 ).

\section{MIC and MBC of seed extracts}

The MIC value of $M$. oleifera seed extracts against the tested bacteria ranged from 6.25 to $25.0 \mathrm{mg} / \mathrm{mL}$. The methanol extract has shown a similar response $(6.25 \mathrm{mg}$ / $\mathrm{mL}$ ) for clinical isolates of E. coli and Shigella dysenteriae, while the MIC value was $12.50 \mathrm{mg} / \mathrm{mL}$ for $E$. coli (ATCC 2592) and Salmonella typhii. The acetone extract has shown similar responses $(6.25 \mathrm{mg} / \mathrm{mL})$ for clinical isolates of E. coli and Salmonella typhii. The MIC value was also found to be similar $(12.50 \mathrm{mg} / \mathrm{mL}$ ) for E. coli (ATCC 2592) and Shigella dysenteriae due to the acetone extract. The aqueous extract has also shown a similar response $(12.50 \mathrm{mg} / \mathrm{mL})$ for clinical isolates of E. coli and Shigella dysenteriae, while the MIC value was 6.25 and $25.00 \mathrm{mg} /$ $\mathrm{mL}$ for E. coli (ATCC 2592) and Salmonella typhii, respectively. Overall, the aqueous extract has exhibited the highest MIC $(25.00 \mathrm{mg} / \mathrm{mL})$ for Salmonella typhii (Table 4). The MBC values for different solvent extracts of $M$. oleifera seed are presented in Table 4 . The maximum $\mathrm{MBC}$ value under the ethanol extract was recorded $12.50 \mathrm{mg} / \mathrm{mL}$ for E. coli (ATCC 2592) and clinical isolates of E. coli and Salmonella typhii; and the minimum $\mathrm{MBC}$ value $(6.25 \mathrm{mg} / \mathrm{mL})$ was with the clinical isolate of Shigella dysenteriae. The acetone extract has shown a similar and maximum response $(12.50 \mathrm{mg} / \mathrm{mL})$ for $E$. coli (ATCC 2592) and clinical isolates of E. coli and Shigella typhii, while it was minimum $(6.25 \mathrm{mg} / \mathrm{mL})$ for Salmonella typhii (clinical isolate). The aqueous extract has shown maximum and similar response $(25.00 \mathrm{mg} / \mathrm{mL})$ for clinical isolates of E. coli, Salmonella typhii and Shigella dysenteriae, while the $\mathrm{MBC}$ value was found minimum (12.50) for E. coli (ATCC 2592) (Table 4).

\section{Discussion}

The two water source samples studied in this investigation are frequently used by the communities living in and surrounding Gondar town. Different turbidity was found for the Angereb (129 NTU) and the Shinta (208.3 NTU) river waters. Drinking water $\mathrm{pH}$ specified by WHO [35] is between 6.5 and 8.5. Both the Shinta and Angereb river

Table 2 Most probable number (MPN) test with various concentrations of Moringa oleifera seed powder

\begin{tabular}{|c|c|c|c|c|c|}
\hline Treatment & Water source & Concentration g/L & Combination of the positives & Coliform counts $/ 100 \mathrm{~mL}$ & $\%$ reduction \\
\hline \multirow[t]{12}{*}{ Seed powder } & Angereb & Control & $5-5-5$ & $>2400$ & 0 \\
\hline & & 0.016 & $5-5-2$ & 500 & 79.17 \\
\hline & & 0.032 & $5-5-0$ & 240 & 90 \\
\hline & & 0.048 & $5-3-2$ & 140 & 94.17 \\
\hline & & 0.064 & $5-3-0$ & 80 & 96.67 \\
\hline & & 0.08 & $5-2-1$ & 70 & 97.08 \\
\hline & Shinta & Control & $5-5-5$ & $>2400$ & 0 \\
\hline & & 0.016 & $5-5-3$ & 900 & 62.5 \\
\hline & & 0.032 & $5-4-4$ & 350 & 85.42 \\
\hline & & 0.048 & $5-4-0$ & 130 & 94.58 \\
\hline & & 0.064 & $5-2-2$ & 90 & 96.25 \\
\hline & & 0.08 & $5-1-2$ & 60 & 97.5 \\
\hline
\end{tabular}


Table 3 Bacterial growth inhibition zones in agar well diffusion method treated with $50 \mathrm{mg} / \mathrm{mL}$ of $\mathbf{m e t h a n o l , ~ a c e t o n e ~}$ and aqueous extract of Moringa oleifera seed

\begin{tabular}{|c|c|c|c|c|c|}
\hline \multirow[t]{3}{*}{ Organisms } & \multicolumn{3}{|c|}{ Zone of inhibition $(\mathrm{mm}) \pm$ standard deviation } & \multirow[t]{3}{*}{ Positive control (ciprofloxacin) } & \multirow[t]{3}{*}{$p$ value using LSD } \\
\hline & \multicolumn{3}{|l|}{ Seeds extract } & & \\
\hline & Methanol & Acetone & Aqueous & & \\
\hline E. coli (ATCC 2592) & $9.66 \pm 0.57^{b}$ & $13.33 \pm 0.57^{c}$ & $8.33 \pm 0.57^{\mathrm{a}}$ & $33.33 \pm 0.57^{d}$ & 0.008 \\
\hline E. coli (clinical isolate) & $15.66 \pm 0.57^{b}$ & $18.00 \pm 0.00^{c}$ & $8.33 \pm 0.57^{\mathrm{a}}$ & $32.66 \pm 2.3^{d}$ & 0.04 \\
\hline Salmonella typhii (clinical isolate) & $15.33 \pm 0.57^{b}$ & $19.00 \pm 0.00^{c}$ & $7.66 \pm 0.57^{\mathrm{a}}$ & $29.33 \pm 0.57^{d}$ & 0.026 \\
\hline Shigella dysenteriae (clinical isolate) & $17.00 \pm 0.00^{b}$ & $18.66 \pm 0.57^{c}$ & $7.66 \pm 1.15^{\mathrm{a}}$ & $29.00 \pm 0.00^{d}$ & 0.003 \\
\hline
\end{tabular}

Means followed by the same letter in a row, are not significantly different at $p=0.05$, using LSD

Table 4 Minimum inhibitory concentration (MIC) and minimum bactericidal concentration (MBC) value of seed extracts of Moringa oleifera

\begin{tabular}{|c|c|c|c|c|c|c|}
\hline \multirow[t]{4}{*}{ Organism } & \multicolumn{6}{|c|}{ Seed extracts } \\
\hline & \multicolumn{2}{|c|}{ Methanol } & \multicolumn{2}{|c|}{ Acetone } & \multicolumn{2}{|c|}{ Aqueous } \\
\hline & \multicolumn{6}{|c|}{$\mathrm{MIC}$ and $\mathrm{MBC} \mathrm{mg} / \mathrm{mL}$} \\
\hline & MIC & MBC & MIC & MBC & MIC & MBC \\
\hline E. coli (ATCC 2592) & 12.5 & 12.5 & 12.5 & 12.5 & 6.25 & 12.50 \\
\hline E. coli (clinical isolate) & 6.25 & 12.5 & 6.25 & 12.5 & 12.5 & 25.0 \\
\hline Salmonella typhii (clinical isolate) & 12.5 & 12.5 & 6.25 & 6.25 & 25.0 & 25.0 \\
\hline Shigella dysenteriae (clinical isolate) & 6.25 & 6.25 & 12.5 & 12.5 & 12.5 & 25.0 \\
\hline
\end{tabular}

water had $\mathrm{pH}$ within the acceptable standards. The addition of $0.016 \mathrm{~g} / \mathrm{L}$ aluminum sulfate has reduced the water $\mathrm{pH}$ from 6.7 and 7.2 to 3.76 and 3.66 for the Angereb and Shinta river water samples, respectively. In municipal water treatment plants, it is a common practice to add lime or soda ash to raise the $\mathrm{pH}$ to acceptable levels. However, $M$. oleifera seed powder did not significantly lower or raise the water $\mathrm{pH}$. This result was consistent with the finding by Arama et al. [36]. In a study, Pal et al. [37] reported that the $M$. oleifera seed powder and leaves extracts have antiulcer and antigastritis activity. Therefore, these characteristics of $M$. oleifera seed, in addition to its low cost, make $M$. oleifera a better alternative for water clarification and it reduces the chances of developing or accelerating ulcers in humans. According to WHO guideline, the turbidity of safe drinking water is less than 5 NTU [35]. In this study, M. oleifera seed powder with a concentration of $0.016 \mathrm{~g} / \mathrm{L}$ has shown great reduction in turbidity in both of the water samples (from 129 NTU to $16.8 \mathrm{NTU}$ (86.98\%) and from 208.3 NTU to 33.66 NTU (83.84\%) for the Angereb and Shinta river water samples, respectively) compared to the negative control. However, aluminum sulfate was the better water purifier as compared to $M$. oleifera since it exhibits more turbidity reduction which conforms to WHO standard with a concentration of $0.016 \mathrm{~g} / \mathrm{L}$ (from $129 \mathrm{NTU}$ to $2.1 \mathrm{NTU}$ (98.37\%) for the Angereb and from 208.3 NTU to 1.86 NTU (99.11\%) for the Shinta water sample.

Pritchard et al. [38] also found that the M. oleifera seed extract reduced the turbidity and number of fecal coliforms in water samples from shallow wells. Similarly, Arama et al. [36] reported a reduction of turbidity at the lowest concentration of $M$. oleifera seed powder treatment. Further in this investigation, when the concentration of $M$. oleifera seed powder was increased from 0.016 to $0.08 \mathrm{~g} / \mathrm{L}$, there was an increase in turbidity. This could be explained by the presence of free positively charged molecules of the flocculants repelling, leading to the flocs floating or suspended in the water $[15,39]$. Such floating flocs could be filtered to achieve lower turbidity. Studies have shown that the maximum reduction in coliform count, as it was done in the most probable number method, was observed at $0.08 \mathrm{~g} / \mathrm{L}$ concentration of $M$. oleifera seed powder from $>2400$ to $70 \mathrm{CFU} / 100 \mathrm{ml}$ (97.08\%) for the Angereb water sample and $>2400$ to $60 \mathrm{CFU} / 100 \mathrm{ml}$ (97.5\%) for the Shinta river sample. Madsen et al. [40] have reported that M. oleifera seeds coagulate $80.0-99.5 \%$ turbidity (surrogate for suspended fine particles) and color (surrogate for natural organic material), efficiently leading to aesthetically clear 
supernatant. As a safer indicator, this was concurrently accompanied by a $90.00-99.99 \%$ bacterial load reduction (fecal coliforms), with bacteria concentrated in the sediment sludge. Unlike this finding, a study conducted by [41] revealed no significant difference in coliform count after the treatment of water sample with different concentrations of $M$. oleifera leaf powder. This might be due to differences in the concentration of the compound which aids to reduce coliforms in different parts of the tree (seed vs. leaf).

The acetone extract prepared by $M$. oleifera seed revealed greater antimicrobial activity to all the experimental organisms followed by the methanol extract, while the aqueous extracts demonstrated the least zone of inhibition. The reduced activity of water extract against microbes investigated in this study is in agreement with previous workers which showed that aqueous extracts of plants generally exhibited little or no antimicrobial activities [4, 42, 43]. Masika and Afolayan [44] reported that gram-negative bacteria are more resistant to water extracts. Furthermore, most researchers [4, 45-47] have reported that water extracts of plants do not have much activity against bacteria. Perhaps, water extracts are different from other solvents which have many compounds that may interact antagonistically in their overall activities. In addition to this, the active compounds of plant materials are not readily extractable in water. Compounds like tannins and polyphenol which are found in M. oleifera are soluble in acetone [48] and have been reported to possess antibacterial activity [49]. It has also been reported that the quality of water treated with $M$. oleifera seed flour is improved through the proteins that promote coagulation [24,50-52]; and coagulant proteins also demonstrated an ability to reduce the density of E. coli, Bacillus thuringiensis and Pseudomonas aeruginosa populations [51].

The MIC value of $M$. oleifera seed extracts against the tested bacteria ranged from $6.25 \mathrm{mg} / \mathrm{mL}$ (acetone extract to all tested organisms and methanol extract of M. oleifera on Shigella dysenteriae-clinical isolate and E. coli-ATCC2592) to $25.00 \mathrm{mg} / \mathrm{mL}$ (aqueous extract of $M$. oleifera on Salmonella typhii-clinical isolate). The most frequent MIC value was $6.25 \mathrm{mg} / \mathrm{mL}$ for the acetone extract. This finding is relatively comparable with the finding by Moyo et al. [53] which showed MIC value of $5.00 \mathrm{mg} / \mathrm{mL}$ of acetone leaf extract of $M$. oleifera for the E. coli. Except for E. coli clinical isolate, the aqueous extract showed a higher MIC value compared to the methanol extract. The MBC value of the extracts was similar $(12.50 \mathrm{mg} / \mathrm{mL})$ for the acetone extract of $M$. oleifera for all experimental organisms except for Salmonella typhii which showed MBC and MIC of $6.25 \mathrm{mg} / \mathrm{mL}$. In contrast to this finding, the acetone extract of leaf of
M. oleifera revealed similar MIC and MBC against E. coli which was $5.00 \mathrm{mg} / \mathrm{mL}$ concentration [53]. It should be noted that for plant materials, there is actually no standard concentration as a model measure for determining the antibacterial activity but Moyo et al. [53], considered $5.00 \mathrm{mg} / \mathrm{mL}$ as their highest concentration level. The corresponding MIC result of its aqueous extract ranged from $12.50 \mathrm{mg} / \mathrm{mL}$ against E. coli (ATCC2592), E. coli (clinical isolate) and Shigella dysenteriae (clinical isolate) to $25 \mathrm{mg} / \mathrm{mL}$ against Salmonella typhii (clinical isolate), while the $\mathrm{MBC}$ of an aqueous extract was quite the same $(25 \mathrm{mg} / \mathrm{mL})$ for all the four organisms except for Salmonella typhii $(12.5 \mathrm{mg} / \mathrm{mL})$.

\section{Conclusion}

Moringa oleifera seed powder has shown a significant reduction of turbidity and coliform count when it was used at smaller concentrations without altering the $\mathrm{pH}$ of the water. Moreover, the extracts of the seed with different solvents showed antibacterial activity to all the four test organisms, i.e., Escherichia coli (ATCC2592), E. coli (clinical isolate), Salmonella typhii (clinical isolate) and Shigella dysenteriae (clinical isolate). The acetone extract is the most effective in inhibiting and killing the test organisms at a very low concentration (MIC and $\mathrm{MBC}=6.25 \mathrm{mg} / \mathrm{mL}$ ) for Salmonella typhii (clinical isolate). The present study has suggested that the acetone extracts of $M$. oleifera seeds have potential as antibacterial compounds against pathogens and their ability to either block or circumvent resistance mechanisms could improve the treatment and eradication of microbial strains. Thus, plant seed extracts could be used in the treatment of infectious diseases caused by microbes. These extracts could probably be promising natural antibacterial agents with potential applications in controlling bacteria that cause waterborne bacterial diseases. Since the acetone extract of the seeds has shown better bactericidal activity, further studies on the isolation of active elements are needed. This investigation facilitates benefits to those who cannot afford and or have access to clean drinking water in Ethiopia and elsewhere. Moreover, a study is also required to optimize the appropriate concentration needed to bring about the reduction in turbidity and coliform count to WHO's standard for effective utilization of the seed for water purification. In this investigation, $M$. oleifera was prefered to pay more attention toward a green and ecofriendly approach which avoids environmental pollution and or contamination.

\section{Authors' contributions}

AD conducted the field and laboratory work. AD, SS and AH wrote the manuscript, reviewed and checked its final version. All authors read and approved the final manuscript. 


\section{Acknowledgements}

Laboratory facilities and assistance provided by the lab staff Department of Biology and Department of Environmental and Occupational Health and Science in Gondar Medical College, University of Gondar, Gondar, Ethiopia, are gratefully acknowledged.

\section{Competing interests}

The author(s) declared no potential conflicts of interest with respect to the research, authorship, and/or publication of this article.

\section{Availability of data and materials}

All available data are tabulated and present in this paper.

\section{Consent for publication}

Not applicable.

\section{Ethics approval and consent to participate}

Not applicable.

\section{Funding}

This research has no fund, except the little number of chemicals are provided by Department of Biology, University of Gondar, P.O. Box 196, Gondar, Ethiopia for this investigation.

\section{Publisher's Note}

Springer Nature remains neutral with regard to jurisdictional claims in published maps and institutional affiliations.

Received: 4 April 2017 Accepted: 17 March 2018

Published online: 25 March 2018

\section{References}

1. Husen A, Mishra VK, Semwal K, Kumar D. Biodiversity status in Ethiopia and challenges. In: Bharati KP, Chauhan A, Kumar P, editors. Environmental pollution and biodiversity, vol. 1. New Delhi: Discovery Publishing House Pvt Ltd; 2012. p. 31-79.

2. Ramasamy S, Charles MA. Antibacterial effect of volatile components of selected medicinal plants against human pathogens. Asian J Microbial Biotech Environ. 2009;6:209-10.

3. Anwar F, Latif S, Ashraf M, Gilan AH. Moringa oleifera: a Food plant with multiple medicinal uses. Phytother Res. 2007;21:17-25.

4. Yibeltal M, Samuel S, Feleke M, Husen A. Antimicrobial activity of crude and semi-purified fractions of Warburgia ugandensis against some pathogens. J Coastal Life Med. 2013;3:184-91.

5. Husen A, Siddiqi KS. Phytosynthesis of nanoparticles: concept, controversy and application. Nano Res Lett. 2014:9:229.

6. Siddiqi KS, Husen A. Fabrication of metal and metal oxide nanoparticles by algae and their toxic effects. Nano Res Lett. 2016;11:363.

7. Siddiqi KS, Husen A. Green synthesis, characterization and uses of palladium/platinum nanoparticles. Nano Res Lett. 2016;11:482.

8. Siddiqi KS, Husen A. Recent advances in plant-mediated engineered gold nanoparticles and their application in biological system. J Trace Elements Med Biol. 2017;40:10-23.

9. Siddiqi KS, Rahman A, Tajuddin Husen A. Biogenic fabrication of iron/iron oxide nanoparticles and their application. Nano Res Lett. 2016;11:498.

10. Husen A. Gold nanoparticles from plant system: Synthesis, characterization and their application. In: Ghorbanpourn M, Manika K, Varma A, editors. Nanoscience and plant-soil systems, vol. 48. Berlin: Springer; 2017. p. 455-79.

11. Faizi S, Siddiqui BS, Saleem R, Aftab K, Shaheen F, Gilani AH. Hypotensive constituents from the pods of Moringa oleifera. Planta Med. 1998:64:225-8.

12. Lalas S, Tsaknis J. Extraction and identification of natural antioxidants from the seeds of Moringa oleifera tree variety of Malavi. J Am Oil Chem Soc. 2002;79:677-83.
13. WHO. Guideline for drinking water quality incorporation first addendum. Vol.1, Recommendations 3rd ed. 2006. http://www.who.int/water.sanitation.health/dwh/qdwa0506.pdf Accessed 15 Sept 2012.

14. UN WWAP. United Nations World Water Assessment Programme. The World Water Development Report 1: Water for People, Water for Life. UNESCO: Paris, France; 2003

15. Sutherland JP, Folkard G, Grant WD. Natural coagulants for appropriate water treatment: a novel approach. Waterlines. 1990;8:30-2.

16. Amagloh FK, Benang A. Effectiveness of Moringa oleifera seed as coagulants for water Purification. Afr J Agric Res. 2007;4:119-23.

17. Futi AP, Otieno WS, Acholla OJ, Otieno WA, Ochieng OS, Mukisira MC. Harvesting surface rainwater-purification using Moringa oleifera seed extracts and aluminum sulphate. J Agric Ext Rur Dev. 2011;3:102-12.

18. Jahn SAA, Musnad HA, Burgstaller $H$. The tree that purifies water: cultivating multipurpose Moringaceae in the Sudan. Unasylva. 1986:38:23-8.

19. Ferreira RS, Napoleão TH, Santos AFS, Sá RA, Carneiro-da-Cunha MG, Morais MMC, Silva-Lucca RA, Oliva MLV, Coelho LCBB, Paiva PMG. Coagulant and antibacterial activities of the water-soluble seed lectin from Moringa oleifera. Lett App Microbiol. 2011;53:186-92.

20. Huntingford GWB. The historical geography of Ethiopia. London: The British Academy; 1989. p. 34.

21. Andargachew B, Samuel S. The effects of Dashen brewery wastewater treatment effluent on the bacteriological and physicochemical quality of Shinta river in Gondar, north west Ethiopia. World Environ. 2013;3:29-36.

22. Akinyemi KO, Oladapo O, Okwara CE, Ibe CC, Fasure KA. Screening of crude extracts of six medicinal plants used in South-West Nigerian unorthodox medicine for antimethicillin resistant S. aureus activity. Biom Coll Compl Altern Med. 2005;5:6347-50

23. Michael L. Low-cost water treatment technologies for developing countries, Ottawa, Ontario. Canada. Curr Protoc Microbiol. 2010;16:1G.2.1-2.14.

24. Ndabigengesere A, Narasiah KS, Talbot BG. Active agents and mechanisms of turbid water using Moringa oleifera. Water Res. 1995;29:703-10.

25. Porter WM. The most probable number method for enumerating infective propagules of vesicular arbuscular mycorrhizal fungi in soils. Aust J Soil Res. 1979;17:515-9.

26. APHA/AWWA/WPCF. Standard methods for the examination of water and wastewater. 20th ed. Washington: American Public Health Association; 1998. p. 1023-31.

27. Woomer PL. Most probable number counts. SSSA Book Series. 1994;5:59-79.

28. Dorea CC. Use of Moringa spp. seeds for coagulation: a review of a sustainable option. Water Sci Technol Water Supp. 2006:6:219-27.

29. Sobsey MD. Managing water in the home: accelerated health gains from improved water supply, prepared for the WHO. Geneva: Water Sanitation and Health Programme; 2002. p. 243-98.

30. National Committee of Clinical Laboratory Standards (NCCLS). Methods for dilution susceptibility tests for bacteria that grow aerobically. 6th edition. Approved standard M7-AS (ISBN 1-56238-377-9). WCCLS, 940, west valley road, suite 1400, Wayne, Pennsylvania, 19087, USA; 2003.

31. Shahidi GA. Evaluation of antimicrobial properties of Iranian medicinal plants against Micrococcus luteus, Serratia marceceans, Klebsiella pneumonia and Bordetella branchoseptica. Asian J Plant Sci. 2004;3:82-6.

32. Lopez V, Jager AK, Akerreta S, Cavero RY, Calvo MI. Pharmacological properties of Anagallis arvensis L. ("scarlet pimpernel") and Anagallis foemina Mill. ("blue pimpernel") traditionally used as wound healing remedies in Navarra (Spain). J Ethnpharmaco. 2011;134:1014-7.

33. Okwori AEJ, Dina CO, Junaid S, Okeke IO, Adetunji JA, Olabode AO. Antibacterial Activities of Ageratum conyzoides extracts on selected bacterial pathogens. Inter J Microbiol. 2007;4:1937-49.

34. Spencer ALR, Spencer JFT. Public health microbiology: methods and protocols. New Jersey: Human Press Inc.; 2004. p. 325-7.

35. WHO. Guidelines for drinking water quality. 3rd Ed, Incorporating 1st and 2nd addenda 1: 668: 2008

36. Arama PF, Wagai SO, Ogur JA, Walter AO, Owido SO, Mahagayu CM. Harvesting surface rainwater-purification using Moringa oleifera seed extracts and aluminum sulfate. J Agric Ext Rur Dev. 2011;3:102-12.

37. Pal SK, Mukherjee PK, Saha K, Pal M, Saha BP. Antimicrobial action of the leaf Extract of Moringa oleifera Lam. Anc Sci Life. 1995;14:197-9.

38. Pritchard M, Mkandawire T, Edmondson A, O'Neill JG, Kululanga G. Potential of using plant extracts for purification of shallow well water in Malawi. Phys Chem Earth. 2009;34:799-805. 
39. Sutherland JP, Folkard GK, Mtawali MA, Grant WD. Moringa oleifera at pilot/full scale. In Pickford, et al. editors; Water, Sanitation, Environment \& Development: Proceedings of the 19th World Economic Development Conference, Accra, Ghana; 1994; p. 109-111.

40. Madsen M, Schlundt J, Omer EF. Effect of water coagulation by seeds of Moringa oleifera on bacterial concentrations. J Trop Med Hygie. 1987;90:101-9.

41. Adejumo OE, Chekujekwy CN, Kolapo AL, Olubamima AO. Chemical analysis and investigative study on water disinfecting properties of (Moringaceae) leaf. J Pharmacol. 2012;3:530-4.

42. Aiyegoro OA, Akinpelu DA, Afolayan AJ, Okoh Al. Antibacterial activities of crude stem bark extracts of Distemonathus benthamianus Baill. J Biol Sci. 2008:8:356-61.

43. Ashafa AOT, Afolayan AJ. Screening the root extracts from Biden pilosa L. var. radiate (Asteraceae) for antimicrobial potentials. J Med Plant Res. 2009;3:568-72.

44. Masika PJ, Afolayan AJ. Antimicrobial activity of some plants used for the treatment of livestock disease in the Eastern Cape, South Africa. J Ethnpharmacol. 2002;83:129-34.

45. Paz EA, Cerdeiras MP, Fernandez J, Ferreira F, Moyna P, Soubes M, Vazquez A, Vero S, Zunio L. Screening of uruguan medicinal plants for antimicrobial activity. J Ethnpharmacol. 1995;45:67-70.
46. Vlientinck AJ, van Hoof L, Lasure A, Vanden D, Rwangabo PC, Mvukiyumwami J. Screening of a hundred Rwandese medicinal plants for ant-microbial and antiviral properties. J Ethnpharmacol. 1995;46:31-47.

47. Martini ND, Eloff JN. The preliminary isolation of several antibacterial compounds from Combretum erythrophyllum (Combretaceae). J Ethnpharmacol. 1998;62:255-63.

48. Makkar HPS, Singh B. Detannification of oak leaves: treatment and the optimization. Ani Feed Sci Technol. 1992;36:13-27.

49. Khosravi A, Behzadi A. Evaluation of the antibacterial activity of the seed hull of Quercus barantii on some gram-negative bacteria. Pak J Med Sci. 2006;22:429-32.

50. Gassenschmidt U, Jany KD, Tauscher B, Niebergall H. Isolation and characterization of a flocculating protein from Moringa oleifera Lam. Biochim Biophys Acta. 1995;1243:477-81.

51. Ghebremichael KA, Gunaratna KR, Henriksson H, Brumer H, Dalhammar G. A simple purification and activity assay of the coagulant protein from Moringa oleifera seed. Water Res. 2005;39:2338-44.

52. Santos AFS, Luz LA, Argolo ACC, Teixeira JA, Paiva PMG, Coelho LCBB. Isolation of a seed coagulant Moringa oleifera lectin. Process Biochem. 2009:44:504-8.

53. Moyo B, Masika PJ, Muchenje V. Antimicrobial activities of Moringa oleifera Lam. leaf extracts. Afri. J Biotechnol. 2012;11:2797-802.

\section{Submit your next manuscript to BioMed Central and we will help you at every step:}

- We accept pre-submission inquiries

- Our selector tool helps you to find the most relevant journal

- We provide round the clock customer support

- Convenient online submission

- Thorough peer review

- Inclusion in PubMed and all major indexing services

- Maximum visibility for your research

Submit your manuscript at www.biomedcentral.com/submit 